\title{
Perancangan Tata Letak Fasilitas Produksi UKM Eko Bubut Menggunakan Metode Automated Layout Design Problem (ALDEP)
}

\author{
Okka Adiyanto, K. Muhd Rizky Paldo \\ Program Studi Teknik Industri, Fakultas Teknologi Industri, Universitas Ahmad Dahlan Yogyakarta, \\ Jalan Ahmad Yani Kampus 4 UAD Ring Road Selatan, Yogyakarta, 55191, Indonesia \\ E-Mail : okka.adiyanto@ie.uad.ac.id, rizkypaldo@gmail.com
}

\begin{abstract}
ABSTRAK
Perancangan tata letak fasilitas produksi merupakan faktor yang mempengaruhi kinerja dari suatu perusahaan. UKM Eko Bubut merupakan sebuah UKM yang memproduksi kerajinan kayu seperti piring kayu. UKM telah beroperasi sejak tahun 2012 hingga saat ini dengan jumlah permintaan yang banyak, namun jumlah pesanan belum dapat dipenuhi. UKM menambahkan departemen kerja dalam kegiatan produksi untuk dapat memenuhi permintaan. Penambahan departemen kerja UKM harus lebih memperhatikan tata letak fasilitas yang baik, karena tata letak fasilitas UKM saat ini terdapat kegiatan back tracking yang jauh dari departemen kerja pengovenan ke departemen kerja pengecatan. UKM saat ini memiliki 12 departemen kerja. Tujuan dari penelitian adalah merancang ulang tata letak untuk menghindari kegiatan back tracking yang tinggi. Metode yang digunakan adalah metode ALDEP. Metode ALDEP merupakan metode yang menghasilkan lebih dari satu layout yang mempertimbangkan tingkat hubungan antar departemen. Setelah dilakukan perancangan tata letak dengan ALDEP, maka didapatkan 7 alternatif layout dengan jarak perpindahan material dan $\mathrm{OMH}$ yang berbeda. Layout alternatif yang dipilih berdasarkan score terbesar yaitu layout alternatif 6 yaitu 513 dengan jarak perpindahan material 104,43 meter dan OMH Rp. 7.632,82.
\end{abstract}

Kata kunci: ALDEP, Ongkos Material Handling, Perancangan Layout, Usaha Kecil Menengah.

\section{Design of Layout Facilities for UKM Eko Bubut Production Using Automated Layout Design Problem (ALDEP) Method}

\begin{abstract}
Design of production facility layout is a factor that affects the performance of a company. Usaha Kecil dan Menengah (UKM) Eko Bubut is an UKM that produces wood crafts such as wooden plates. UKM has been operating since 2012 until now with a large number of requests, however, the number of orders cannot be fulfilled. UKM adds work department in the production activities to meet the demand. The addition of UKM work department have to consider the good facility layout, since the current facility layout has back tracking activities that are far from the oven department to the painting department. Currently UKM has 12 work departments. The purpose of this research is to redesign the layout to avoid high back tracking activities. The method used is the Automated Layout Design Program (ALDEP). ALDEP is a method that produces more than one layout that considers the level of relationships between departments. After designing the layout with ALDEP, we found 6 alternative layouts with different material transfer distances and Material Handling Cost (OMH). Alternative layout selected based on the biggest score is alternative layout 6, namely 513 with material displacement distance of 104.43 meters and OMH Rp. 7,632.82.
\end{abstract}

Keywords: ALDEP, Layout Design, Material Handling Cost, Small Medium Enterprises. 


\section{Pendahuluan}

Perkembangan UKM di Indonesia saat ini berkembang sangat cepat. Perkembangan ini diiringi dengan tumbuhnya industri kreatif di Indonesia. Pengembangan salah satu UKM yang bergerak dalam Industri kreatif yaitu UKM Eko Bubut. UKM Eko Bubut terletak di dusun Gumawang Kecamatan Patuk Kabupaten Gunung Kidul. UKM Eko Bubut merupakan UKM yang memproduksi kerajinan kayu seperti piring kayu, sendok kayu, mangkok kayu, dll. UKM telah beroperasi sejak tahun 2012 hingga saat ini dengan jumlah permintaan yang mencapai 2000 buah per bulan. UKM Eko Bubut untuk memperoleh keberhasilan sesuai dengan tujuan dana rah yang ingin dicapai maka diperlukan perencanaan yang harus disiapkan dan dirancangan dengan baik (Rosyidi, 2018).

Permasalahan yang muncul pada UKM Eko Bubut tersebut yaitu UKM Eko Bubut belum mampu memenuhi permintaan pelanggan tersebut dikarenakan terjadinya penumpukan bahan baku yang akan diproduksi. Selain penumpukan bahan baku pada tata letak produksi di UKM Eko Bubut saat ini terdapat kegiatan back tracking yang ternilai jauh. Back tracking yang timbul pada proses produksi ini terletak pada perpindahan dari departemen kerja pengovenan ke departemen kerja pengecatan.

Beberapa kondisi tersebut dapat menghambat proses produksi di UKM Eko Bubut dan menyebabkan kerugian dari pihak UKM Eko Bubut. Maka dari itu, perlu dilakukan perancangan tata letak usulan yang lebih efisien dan memiliki jarak perpindahan paling minimal, serta alur produksi yang teratur.

Salah satu cara agar dapat menyelesaikan permasalahan tersebut maka diperlukan re-layout fasilitas produksi di UKM Eko Bubut. Re-layout ini diharapkan dapat menyelesaikan masalah yang ada pada UKM Eko Bubut. Selain itu dari re-layout ini dapat membantu pemenuhan permintaan konsumen sehingga proses produksi akan lebih cepat dan dapat memproduksi lebih banyak.
Definisi tata letak fasilitas adalah suatu tata cara pengaturan fasilitas-fasilitas produksi guna menunjang proses produksi (Wignjosoebroto, 2009). Tujuan dari perancangan tata letak fasilitas produksi sendiri adalah untuk menentukan bagaimana hubungan stasiun kerja dari setiap fasilitas produksi diatur sehingga mencapai kegiatan produksi yang efisien dan efektif, serta kegiatan-kegiatan produksi menjadi lebih lancar.

Tata letak memiliki banyak dampak strategis karena tata letak menentukan daya saing perusahaan dalam hal kapasitas, proses, fleksibilitas, biaya, kualitas lingkungan kerja, kontak dengan pelanggan dan citra perusahaan (Maheswari \& Dany Firdauzy, 2015).

Perancangan tata letak meliputi pengaturan tata letak fasilitas-fasilitas operasi dengan memanfaatkan area yang tersedia untuk penempatan mesin-mesin, bahanbahan perlengkapan untuk operasi, dan semua peralatan yang digunakan dalam proses operasi (Wahyudi, 2010). Selain itu dalam perancangan tata letak fasilitas juga diatur personalia yang digunakan dalam proses produksi (Purnomo, 2004). Perancangan ulang tata letak dapat mengoptimalkan beban kerja operator (Tarigan, Tarigan, \& Dalimunthe, 2017).

Perancangan tata letak fasilitas berperan penting sebagai berikut (James M. Apple, 1990):

1) Suatu perencanaan aliran barang yang efisien merupakan prasyarat untuk mendapatkan produksi yang ekonomis.

2) Pola aliran barang yang merupakan dasar bagi perencanaan fasilitas fisik yang efektif.

3) Perpindahan barang merubah pola aliran statis menjadi suatu kenyataan yang dinamis, menunjukkan cara bagaimana suatu barang dipindahkan.

4) Susunan fasilitas yang efektif disekitar pola aliran barang dapat menghasilkan pelaksanaan yang efisien dapat meminimumkan biaya produksi. 
5) Biaya produksi minimum dapat memberikan keuntungan maksimum.

Salah satu metode dalam tata letak fasilitas yang dapat dipergunakan dalam pemecahan masalah pada UKM Eko Bubut yaitu dengan metode ALDEP (Automated Layout Design Program). Menurut (Aleisa \& Lin, 2005) metode evaluasi tata letak yang dipergunakan dengan Algoritma Layout Design Program (ALDEP) adalah dengan cara mencari departemen-departemen yang berbatasan secara langsung. Pemilihan metode ini dikarenakan metode Algoritma Layout Design Program (ALDEP) termasuk dalam metode konstruksi dimana metode ini akan menghasilkan tata letak baru tanpa memandang tata letak yang ada atau existing layout sehingga cocok untuk pemecahan masalah di UKM Eko Bubut ini.

Perbedaan utama pada model-model konstruksi ini mengacu pada kriteria yang digunakan untuk menentukan fasilitas pertama yang masuk pada layout tata letak dan fasilitas berikutnya hingga jadi menjadi tata letak yang baru (Tika Pamularsih, Fifi Herni Mustofa, \& Susy Susanty, 2015).

Beberapa penelitian yang sudah menggunakan Metode Algoritma Layout Design Program (ALDEP) salah satunya adalah penelitian dari Andryzio, Fifi Herni dan Lisye Fitria dengan judul Usulan Perancangan tata letak fasilitas dengan menggunakan Metode Algoritma Layout Design Program (ALDEP) di CV. Kawani Tekno Nusantara. Pada penelitian yang sudah dilakukan didapatkan hasil 5 alternatif rancnagan dan alternative yang dipilih adalah alternative yang memiliki nilai TCR (Total clossness rating) terbesar (Andryzio, Fifi Herni Mustofa, \& Lisye Fitria, 2014).

Penelitian selanjutnya yaitu memiliki judul Usulan Rancangan Tata Letak Fasilitas Produksi Produk Selang Dengan Menggunakan Automated Layout Design Program (AlDEP) Di PT. Inkaba Bandung oleh Ananda Rosalina, Susy Susanty, dan Fifi Herni. Pada penelitian mereka Perancangan ulang tata letak fasilitas dengan menggunakan Automated Layout Design Program (ALDEP) menghasilkan tiga alternatif Area Alocating Diagram (AAD) yang dihasilkan dari satu tata letak terbaik berdasarkan nilai Total Clossenes Rating (TCR) terbesar. Dari ketiga alternatif AAD yang dihasilkan, AAD terbaik berada pada AAD alternatif 3 yang menghasilkan total $\mathrm{OMH}$ dan jumlah backtracking paling kecil (Ulfa, Susanty, \& Mustofa, 2015).

Penelitian lain selanjutnya berjudul Pennetuan lokasi dan Perancangan tata letak fasilitas tempat Packaging PT ABC oleh Christina Natalia Rubianto dan Liem Yenny Bendatu. Pada penelitian ini membandingan dengan 2 metode ALDEP dan CORELAP. Hasil layout terbaik akan digunakan untuk initial layout untuk metode CRAFT. Metode CRAFT dilakukan dengan melakukan pertukaran-pertukaran antara departemen untuk mendapatkan momen yang lebih kecil (Rubianto \& Bendatu, 2014).

Usulan Layout pada penelitian ini menggunakan Metode Algoritma Layout Design Program (ALDEP). Metode Automated Layout Design Program (ALDEP) dipilih karena dapat menghasilkan tata letak yang memperhatikan keterkaitan antar departemen kerja, alur produksi, dan jarak perpindahan. Pada perancangan dengan algoritma ALDEP terbagi atas 2 prosedur, yaitu prosedur pemilihan dan penempatan. Ada beberapa layout yang didapatkan kemudian akan dihitung score masingmasing layout yang dihasilkan dan selanjutnya dipilih layout score terbaik (Tompkins, White, Bozer, \& Tanchoco, 2010).

\section{Metodologi}

Objek penelitian yang diamati adalah tataletak pada bagian produksi UKM Eko Bubut dan produk yang diamati adalah produk piring kayu. Pemilihan piring kayu ini dikarenakan dalam proses produksi produk piring kayu merupakan produk yang paling banyak menggunakan departemen kerja.

Tahap awal penelitian yaitu pendahuluan untuk mengetahui kondisi awal dengan 
observasi langsung ke tempat penelitian dan wawancara. Setelah itu mengidentifikasi masalah yang terdapat pada lantai produksi tempat penelitian, dan menetapkan masalah yang terdapat di tempat penelitian. Tahapan selanjutnya adalah melakukan pengumpulan data dengan pengamatan dan pengukuran secara langsung pada lantai produksi tempat penelitian dengan bantuan alat berupa meteran. Kemudian menganalisa kondisi awal lantai produksi tempat penelitian seperti jarak perpindahan material dan Ongkos Material Handling (OMH).

Manfaat mengetahui $\mathrm{OMH}$ ini menurut (Yuliant, Saleh, \& Bakar, 2014) yaitu untuk melihat pengaruh dari pola aluran barang terhadap keuntungan sebuah perusahaan. Setelah dilakukan analisa kondisi awal, selanjutnya merancang layout dengan metode ALDEP dan selanjutnya membandingkan hasil analisa kondisi awal dengan hasil perancangan layout dengan metode ALDEP.

\section{Hasil dan Pembahasan}

Penelitian ini melakukan kegiatan berupa pengumpulan data dan pengolahan data. Pengumpulan data yang diamati pada penelitian ini adalah aliran bahan, urutan proses produksi, pemindahan material, jarak pemindahan bahan, dan ongkos material handling (OMH). Setelah pengumpulan data, dilanjutkan kegiatan pengolahan data dengan Algoritma ALDEP. Perancangan tata letak dengan metode ALDEP terbagi menjadi 2 prosedur, yaitu prosedur pemilihan dan prosedur penempatan.

Hasil rancangan dari algoritma ALDEP tersebut digambarkan ke dalam tabel luas Departemen. Perhitungan luas Departemen dapat dilihat pada Tabel 1.

Tabel 1. Luas Departemen

\begin{tabular}{ccclcc}
\hline $\begin{array}{c}\text { No } \\
\text { Dept }\end{array}$ & Kode & & Departemen & $\begin{array}{c}\text { Luas } \\
\text { Departemen } \\
\left(\text { meter }^{2}\right)\end{array}$ & $\begin{array}{c}\text { Luas } \\
\text { Departemen } \\
(\text { sel) }\end{array}$ \\
\hline 1 & A & Persiapan & Gudang Bahan Baku & 3,50 & 4 \\
2 & B & & Pemolaan & 2,36 & 3 \\
3 & C & \multirow{2}{*}{ Pemotongan } & Gergaji Mesin & 1,16 & 2 \\
4 & D & & Circle & 4,75 & 5 \\
5 & E & \multirow{2}{*}{ Pembubutan } & Bubut Luar & 4,27 & 5 \\
6 & F & \multirow{2}{*}{ Bubut Dalam } & 4,27 & 5 \\
7 & G & Pengamplasan & Gerinda & 0,93 & 1 \\
8 & H & & Pengovenan & 0,48 & 1 \\
9 & I & \multirow{2}{*}{ Finishing } & Pengecatan & 2,71 & 3 \\
10 & J & & Gudang Produk Jadi & 1,66 & 2 \\
& & & & 26,09 & 31 \\
\hline
\end{tabular}

Setelah perancangan tata letak dengan algoritma ALDEP selesai, dilanjutkan dengan melakukan perhitungan jarak perpindahan dan perhitungan jumlah ongkos material handling $(\mathrm{OMH})$ yang dikeluarkan dari layout awal maupun layout usulan. Perhitungan nilai ongkos material handling (OMH) didapat dari jumlah biaya penanganan bahan dan karyawan pada Tabel 2. 
Tabel 2. Jumlah Biaya Penanganan Bahan dan Karyawan

\begin{tabular}{crrrr}
\hline Jenis Biaya & per bulan & per hari & per jam & jam kerja/hari \\
\hline Gaji Karyawan & 1.500 .000 & 50.000 & 6.250 & \\
Biaya Gerobak & 25.000 & 833,33 & 104,17 & 8 \\
Total & 1.525 .000 & $50.833,33$ & $6.354,17$ & \\
\hline
\end{tabular}

Tahapan sel anjutnya adalah melakukan pengumpulan data dengan pengamatan dan pengukuran secara langsung pada lantai produksi UKM Eko Bubut dengan bantuan alat berupa meteran ukur. Tata Letak fasilitas awal UKM Eko Bubut dapat dilihat pada Gambar 1 dan data ukuran pada lantai produksi dan pengkodean dapat dilihat pada Tabel 3.

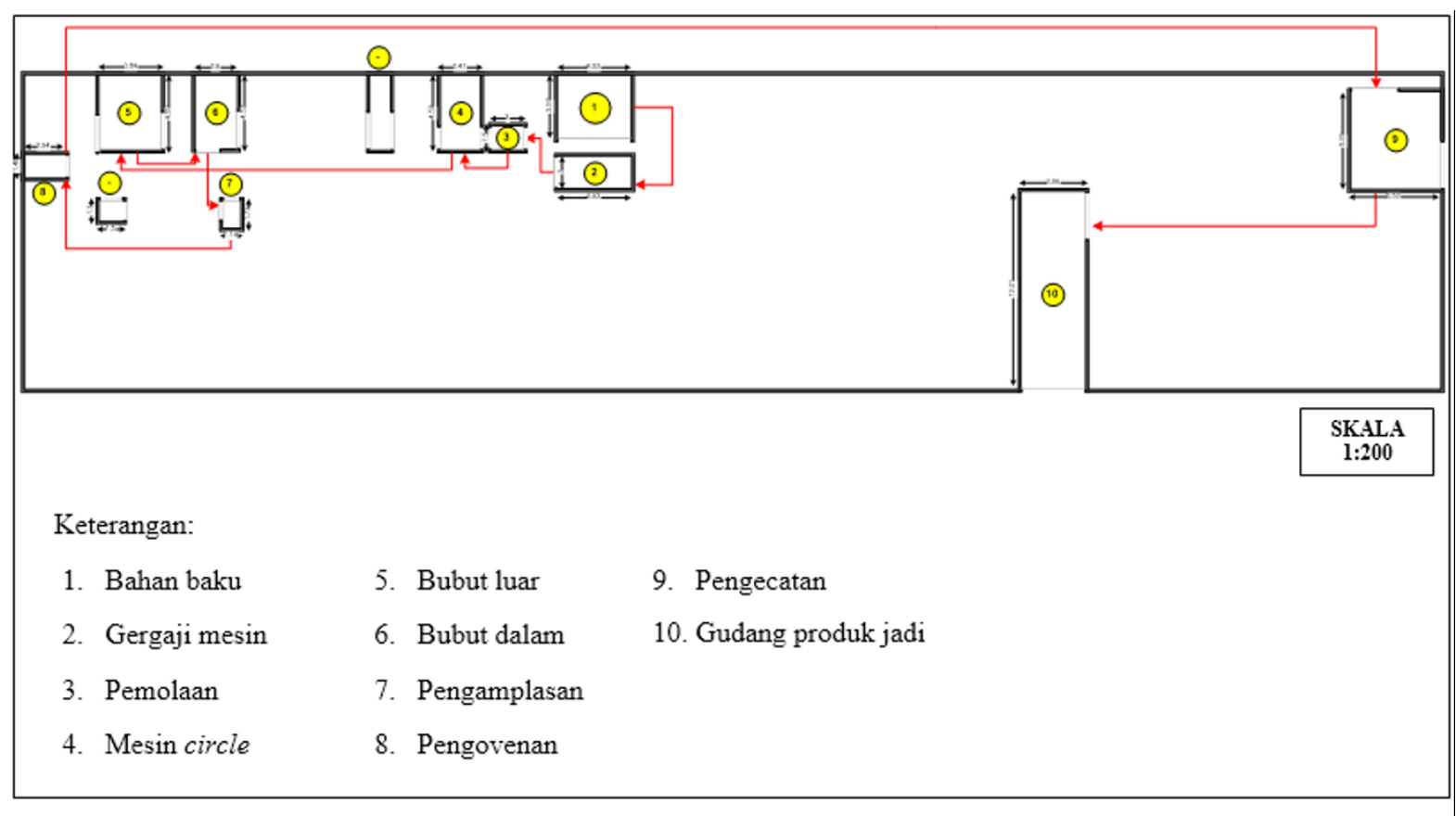

Gambar 1. Tata Letak Fasilitas Awal UKM Eko Bubut

Tabel 3. Pengkodean Departemen Kerja

\begin{tabular}{lccc}
\hline \multicolumn{1}{c}{ Departemen Kerja } & $\begin{array}{c}\text { Ukuran Area } \\
(\mathrm{m})\end{array}$ & $\begin{array}{c}\text { Luas } \\
(\mathrm{m})\end{array}$ & Kode \\
\hline Bahan baku & $3,92 \times 4,52$ & 17,72 & 1 \\
Proses pemotongan gergaji mesin & $2 \times 4,52$ & 9,04 & 2 \\
Proses pemolaan & $1,5 \times 2$ & 3 & 3 \\
Proses pemotongan mesin circle & $2,47 \times 4,59$ & 11,34 & 4 \\
Proses pembubutan bagian luar & $3,84 \times 4,59$ & 17,63 & 5 \\
Proses pembubutan bagian dalam & $2,6 \times 4,52$ & 11,75 & 6 \\
Pengamplasan mesin gerinda & $1,5 \times 1,3$ & 1,95 & 7 \\
Proses pengovenan & $2,54 \times 1,46$ & 3,71 & 8 \\
Proses pengecatan & $5,59 \times 5,52$ & 30,86 & 9 \\
Gudang produk jadi & $3,96 \times 12,01$ & 47,56 & 10 \\
\hline
\end{tabular}


Langkah selanjutnya yaitu membuat derajat hubungan kedekatan dengan kriteria yang telah berdasarkan kondisi di lantai produksi UKM Eko Bubut.Derajat hubungan kedekatan atau Activity Relation Chart yang menggunakan kombinasi anatara analisa aliran material dan juga analisa aktivitas (activity relationship) (Prasetya, Runtuk, \& Hartanti, 2015). ARC di lantai produksi UKM Eko Bubut dapat dilihat pada Gambar 2.

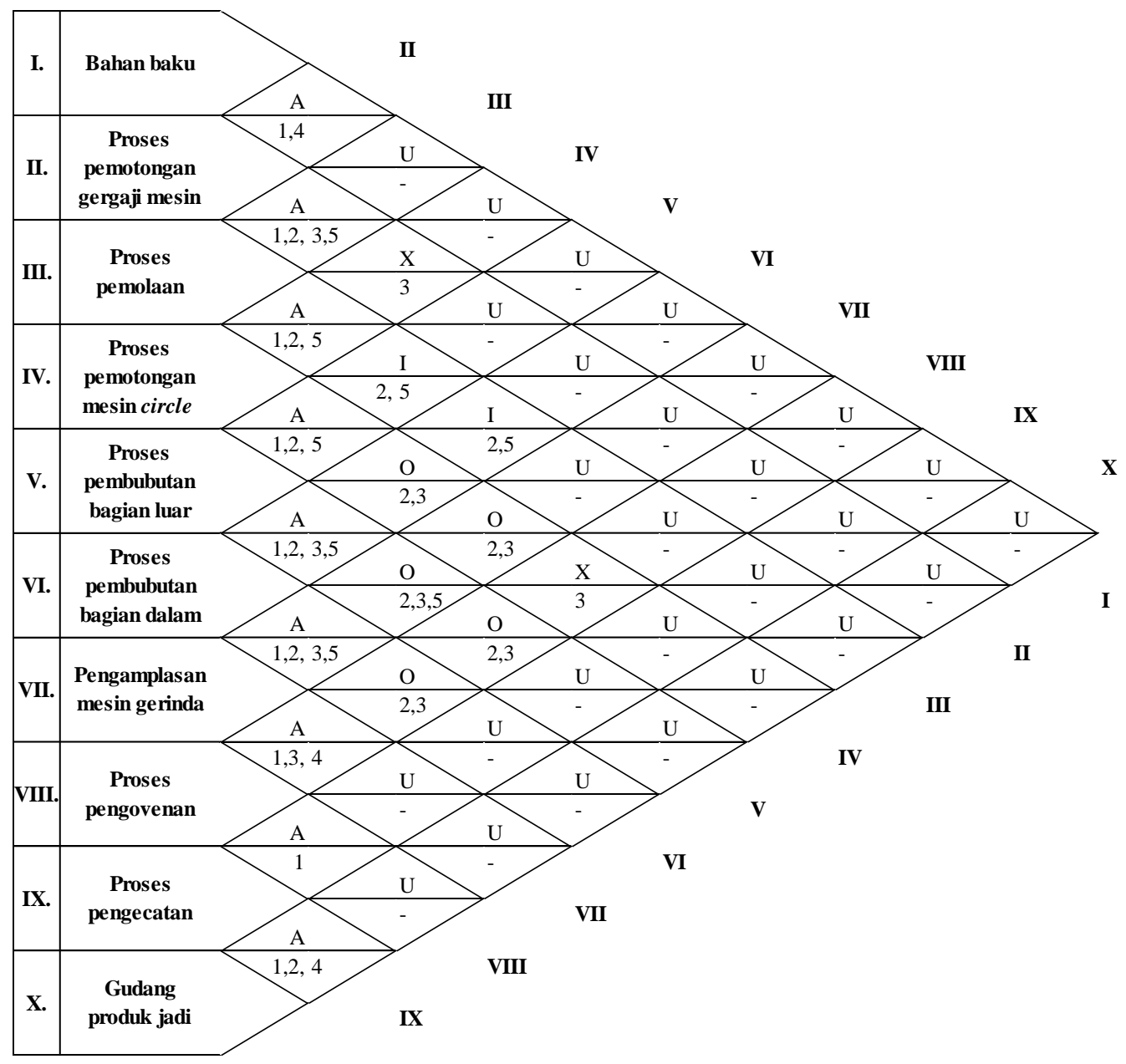

Gambar 2. ARC UKM Eko Bubut

Setelah didapat ARC UKM Eko Bubut, maka dilakukan perhitungan jarak perpindahan dan $\mathrm{OMH}$ awal dapat dilihat pada Tabel 4, kemudian dilanjutkan semua langkah-langkah pengerjaan dengan algoritma ALDEP serta perhitungan jarak perpindahan dan $\mathrm{OMH}$ layout hingga mendapatkan hasil terbaik.

Pada Tabel 4 didapatkan hasil jarak perpindahan dan $\mathrm{OMH}$ awal sebesar 121,69 meter dan Rp 8.925,84.-. Dari hasil pengolahan menggunakan metode ALDEP maka didapat 6 alternatif usulan yang terbentuk. 
Tabel 4. Total OMH awal

\begin{tabular}{|c|c|c|c|c|c|c|c|c|c|}
\hline No & From & To & $\begin{array}{c}\text { Jarak } \\
\text { (m) }\end{array}$ & $\begin{array}{c}\text { Total } \\
\text { Jarak } \\
\text { (m) }\end{array}$ & $\begin{array}{c}\text { Jenis } \\
\text { Transport }\end{array}$ & $\begin{array}{c}\text { Biaya } \\
\text { Transport }\end{array}$ & OMH per meter & $\mathrm{OMH}$ & $\begin{array}{l}\text { Total } \\
\text { OMH }\end{array}$ \\
\hline 1 & $\begin{array}{c}\text { Bahan } \\
\text { baku }\end{array}$ & $\begin{array}{l}\text { Pemotongan } \\
\text { gergaii mesin }\end{array}$ & 1 & 121,69 & $\begin{array}{l}\text { Tenaga } \\
\text { manusia }\end{array}$ & 50000 & 72,57 & 72,57 & \\
\hline 2 & $\begin{array}{l}\text { Pemotongan } \\
\text { gergaji mesin }\end{array}$ & Pemolaan & 2 & & $\begin{array}{l}\text { Tenaga } \\
\text { manusia }\end{array}$ & & & 145,15 & \\
\hline 3 & Pemolaan & $\begin{array}{l}\text { Pemotongan } \\
\text { mesin circle }\end{array}$ & 0,64 & & $\begin{array}{c}\text { Tenaga } \\
\text { manusia }\end{array}$ & & & 46,45 & \\
\hline 4 & $\begin{array}{l}\text { Pemotongan } \\
\text { mesin circle }\end{array}$ & $\begin{array}{c}\text { Pembubutan } \\
\text { bagian luar }\end{array}$ & 16,92 & & $\begin{array}{l}\text { Tenaga } \\
\text { manusia }\end{array}$ & & & 1227,94 & \\
\hline 5 & $\begin{array}{l}\text { Pembubutan } \\
\text { bagian luar }\end{array}$ & $\begin{array}{l}\text { Pembubutan } \\
\text { bagian dalam }\end{array}$ & 2 & & $\begin{array}{l}\text { Tenaga } \\
\text { manusia }\end{array}$ & & & 145,15 & 8925,84 \\
\hline 6 & $\begin{array}{l}\text { Pembubutan } \\
\text { bagian dalam }\end{array}$ & $\begin{array}{c}\text { Pengamplasan } \\
\text { mesin gerinda }\end{array}$ & 3 & & $\begin{array}{l}\text { Tenaga } \\
\text { manusia }\end{array}$ & & & 217,72 & \\
\hline 7 & $\begin{array}{l}\text { Pengamplasan } \\
\text { mesin gerinda }\end{array}$ & Pengovenan & 2 & & $\begin{array}{l}\text { Tenaga } \\
\text { manusia }\end{array}$ & & & 145,15 & \\
\hline 8 & Pengovenan & Pengecatan & 78,06 & & $\begin{array}{l}\text { Tenaga manusia } \\
\text { (Gerobak) }\end{array}$ & 50833,33 & 73,78 & 5759,48 & \\
\hline 9 & Pengecatan & $\begin{array}{c}\text { Gudang } \\
\text { produk jadi }\end{array}$ & 16,07 & & $\begin{array}{l}\text { Tenaga } \\
\text { manusia }\end{array}$ & 50000 & 72,57 & 1166,25 & \\
\hline
\end{tabular}

\subsection{Alternatif 1}

Layout alternatif 1 memiliki jarak perpindahan material sebesar 148,68 meter dan ongkos material handling (OMH) sebesar Rp. 10.819,28.- per hari dapat dilihat pada Tabel 5 dan memiliki nilai score ALDEP sebesar -700 pada Gambar 3.

\subsection{Alternatif 2}

Layout alternatif 2 memiliki jarak perpindahan material sebesar 233,46 meter dan ongkos material handling (OMH) sebesar Rp. 17.006,8.- per hari dapat dilihat pada Tabel 6 dan memiliki nilai score ALDEP sebesar -764 pada Gambar 4.

\subsection{Alternatif 3}

Layout alternatif 3 memiliki jarak perpindahan material sebesar 171,76 meter dan ongkos material handling $(\mathrm{OMH})$ sebesar Rp. 12.465,5.- per hari dapat dilihat pada Tabel 7 dan memiliki nilai score ALDEP sebesar -766 dapat dilihat pada Gambar 5.

\subsection{Alternatif 4}

Layout alternatif 4 memiliki jarak perpindahan material sebesar 185,14 meter dan ongkos material handling (OMH) sebesar Rp. 13.464,53.- per hari dapat dilihat pada Tabel 8 dan memiliki nilai score ALDEP sebesar 261 pada Gambar 6.

\subsection{Alternatif 5}

Layout alternatif 5 memiliki jarak perpindahan material sebesar 131,18 meter dan ongkos material handling $(\mathrm{OMH})$ sebesar Rp. 9.614,56.- per hari dapat dilihat pada Tabel 9 dan memiliki nilai score ALDEP sebesar 328 dapat dilihat pada Gambar 7. 


\subsection{Alternatif 6}

Layout alternatif 6 memiliki jarak perpindahan material sebesar 104,43 meter dan ongkos material handling (OMH) sebesar Rp. 7.632,82.- per hari dapat dilihat pada
Tabel 10 dan memiliki nilai score ALDEP sebesar 513 pada Gambar 8 .

Tabel 5. Nilai OMH Alternatif 1

\begin{tabular}{|c|c|c|c|c|c|c|c|c|c|}
\hline No & From & To & $\begin{array}{c}\text { Jarak } \\
\text { (m) }\end{array}$ & $\begin{array}{c}\text { Total } \\
\text { Jarak } \\
(\mathbf{m})\end{array}$ & $\begin{array}{c}\text { Jenis } \\
\text { Transport }\end{array}$ & $\begin{array}{c}\text { Biaya } \\
\text { Transport }\end{array}$ & OMH per meter & OMH & $\begin{array}{l}\text { Total } \\
\text { OMH }\end{array}$ \\
\hline 1 & $\begin{array}{c}\text { Bahan } \\
\text { baku }\end{array}$ & $\begin{array}{l}\text { Pemotongan } \\
\text { gergaji mesin }\end{array}$ & 3,64 & & $\begin{array}{l}\text { Tenaga } \\
\text { manusia }\end{array}$ & & & 264,17 & \\
\hline 2 & $\begin{array}{l}\text { Pemotongan } \\
\text { gergaji mesin }\end{array}$ & Pemolaan & 7,44 & & $\begin{array}{l}\text { Tenaga } \\
\text { manusia }\end{array}$ & & & 539,94 & \\
\hline 3 & Pemolaan & $\begin{array}{l}\text { Pemotongan } \\
\text { mesin circle }\end{array}$ & 18,15 & & $\begin{array}{l}\text { Tenaga } \\
\text { manusia }\end{array}$ & & & 1317,20 & \\
\hline 4 & $\begin{array}{l}\text { Pemotongan } \\
\text { mesin circle }\end{array}$ & $\begin{array}{c}\text { Pembubutan } \\
\text { bagian luar }\end{array}$ & 2,06 & & $\begin{array}{l}\text { Tenaga } \\
\text { manusia }\end{array}$ & 50000 & 72,57 & 149,50 & \\
\hline 5 & $\begin{array}{c}\text { Pembubutan } \\
\text { bagian luar }\end{array}$ & $\begin{array}{l}\text { Pembubutan } \\
\text { bagian dalam }\end{array}$ & 16,85 & 148,68 & $\begin{array}{l}\text { Tenaga } \\
\text { manusia }\end{array}$ & & & 1222,86 & 10819,28 \\
\hline 6 & $\begin{array}{l}\text { Pembubutan } \\
\text { bagian dalam }\end{array}$ & $\begin{array}{c}\text { Pengamplasan } \\
\text { mesin gerinda }\end{array}$ & 7,96 & & $\begin{array}{l}\text { Tenaga } \\
\text { manusia }\end{array}$ & & & 577,68 & \\
\hline 7 & $\begin{array}{c}\text { Pengamplasan } \\
\text { mesin gerinda }\end{array}$ & Pengovenan & 25,08 & & $\begin{array}{l}\text { Tenaga } \\
\text { manusia }\end{array}$ & & & 1820,13 & \\
\hline 8 & Pengovenan & Pengecatan & 24,06 & & $\begin{array}{c}\text { Tenaga manusia } \\
\text { (Gerobak) }\end{array}$ & 50833,33 & 73,78 & 1775,21 & \\
\hline 9 & Pengecatan & $\begin{array}{c}\text { Gudang } \\
\text { produk jadi }\end{array}$ & 43,44 & & $\begin{array}{r}\text { Tenaga } \\
\text { manusia } \\
\end{array}$ & 50000 & 72,57 & 3152,58 & \\
\hline
\end{tabular}

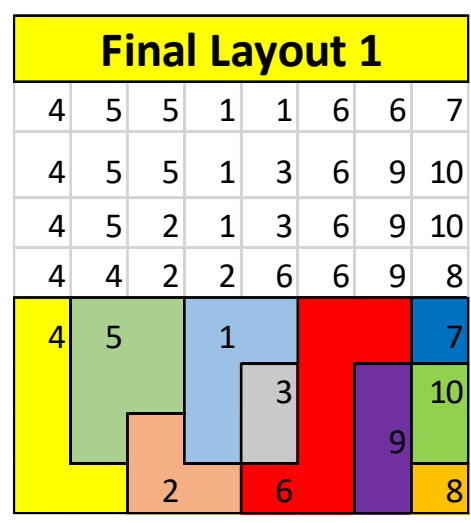

\begin{tabular}{ccc}
\hline $\begin{array}{c}\text { Adjacency } \\
\text { Departemen }\end{array}$ & Hubungan & Nilai Score \\
\hline $4-5$ & $\mathrm{~A}$ & 64 \\
$4-2$ & $\mathrm{X}$ & -1024 \\
$5-2$ & $\mathrm{U}$ & 0 \\
$5-1$ & $\mathrm{U}$ & 0 \\
$2-1$ & $\mathrm{~A}$ & 64 \\
$2-6$ & $\mathrm{U}$ & 0 \\
$1-3$ & $\mathrm{U}$ & 0 \\
$1-6$ & $\mathrm{U}$ & 0 \\
$3-6$ & $\mathrm{I}$ & 4 \\
$6-9$ & $\mathrm{U}$ & 0 \\
$6-7$ & $\mathrm{~A}$ & 64 \\
$9-8$ & $\mathrm{~A}$ & 64 \\
$9-10$ & $\mathrm{~A}$ & 64 \\
$8-10$ & $\mathrm{U}$ & 0 \\
$10-7$ & $\mathrm{U}$ & 0 \\
& & $\mathbf{7 0 0}$ \\
\hline
\end{tabular}

Gambar 3. Layout 1 dan Nilai Score 
Tabel 6. Nilai OMH Alternatif 2

\begin{tabular}{|c|c|c|c|c|c|c|c|c|c|}
\hline No & From & To & $\begin{array}{c}\text { Jarak } \\
\text { (m) }\end{array}$ & $\begin{array}{c}\text { Total } \\
\text { Jarak } \\
(\mathbf{m}) \\
\end{array}$ & $\begin{array}{c}\text { Jenis } \\
\text { Transport }\end{array}$ & $\begin{array}{c}\text { Biaya } \\
\text { Transport }\end{array}$ & OMH per meter & ОМН & $\begin{array}{l}\text { Total } \\
\text { OMH }\end{array}$ \\
\hline 1 & $\begin{array}{l}\text { Bahan } \\
\text { baku }\end{array}$ & $\begin{array}{l}\text { Pemotongan } \\
\text { gergaji mesin }\end{array}$ & 47,34 & & $\begin{array}{l}\text { Tenaga } \\
\text { manusia }\end{array}$ & & & 3435,61 & \\
\hline 2 & $\begin{array}{l}\text { Pemotongan } \\
\text { gergaji mesin }\end{array}$ & Pemolaan & 2,17 & & $\begin{array}{l}\text { Tenaga } \\
\text { manusia }\end{array}$ & & & 157,48 & \\
\hline 3 & Pemolaan & $\begin{array}{l}\text { Pemotongan } \\
\text { mesin circle }\end{array}$ & 31,44 & & $\begin{array}{l}\text { Tenaga } \\
\text { manusia }\end{array}$ & & & 2281,70 & \\
\hline 4 & $\begin{array}{l}\text { Pemotongan } \\
\text { mesin circle }\end{array}$ & $\begin{array}{l}\text { Pembubutan } \\
\text { bagian luar }\end{array}$ & 0,33 & & $\begin{array}{l}\text { Tenaga } \\
\text { manusia }\end{array}$ & 50000 & 72,57 & 23,95 & \\
\hline 5 & $\begin{array}{l}\text { Pembubutan } \\
\text { bagian luar }\end{array}$ & $\begin{array}{l}\text { Pembubutan } \\
\text { bagian dalam }\end{array}$ & 19,74 & 233,46 & $\begin{array}{l}\text { Tenaga } \\
\text { manusia }\end{array}$ & & & 1432,59 & 17006,8 \\
\hline 6 & $\begin{array}{l}\text { Pembubutan } \\
\text { bagian dalam }\end{array}$ & $\begin{array}{l}\text { Pengamplasan } \\
\text { mesin gerinda }\end{array}$ & 3,33 & & $\begin{array}{l}\text { Tenaga } \\
\text { manusia }\end{array}$ & & & 241,67 & \\
\hline 7 & $\begin{array}{c}\text { Pengamplasan } \\
\text { mesin gerinda }\end{array}$ & Pengovenan & 75,19 & & $\begin{array}{l}\text { Tenaga } \\
\text { manusia }\end{array}$ & & & 5456,78 & \\
\hline 8 & Pengovenan & Pengecatan & 52,83 & & $\begin{array}{c}\text { Tenaga manusia } \\
\text { (Gerobak) }\end{array}$ & 50833,33 & 73,78 & 3897,94 & \\
\hline 9 & Pengecatan & $\begin{array}{c}\text { Gudang } \\
\text { produk jadi }\end{array}$ & 1,09 & & $\begin{array}{l}\text { Tenaga } \\
\text { manusia }\end{array}$ & 50000 & 72,57 & 79,10 & \\
\hline
\end{tabular}

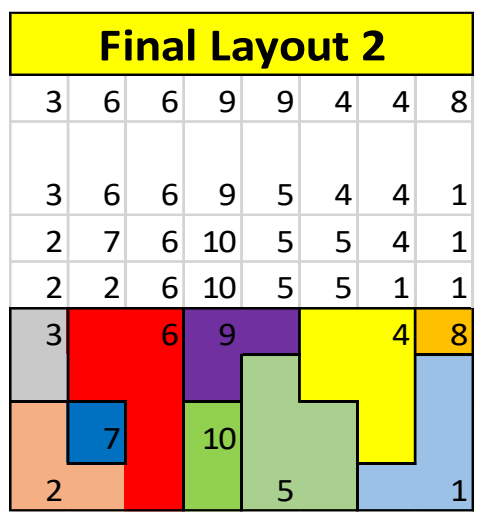

\begin{tabular}{|c|c|c|}
\hline $\begin{array}{l}\text { Adjacency } \\
\text { Departemen }\end{array}$ & Hubungan & Nilai Score \\
\hline $3-2$ & A & 64 \\
\hline $3-6$ & I & 4 \\
\hline $2-7$ & $\mathrm{U}$ & 0 \\
\hline $2-6$ & $\mathrm{U}$ & 0 \\
\hline $7-6$ & $\mathrm{~A}$ & 64 \\
\hline $6-10$ & $\mathrm{U}$ & 0 \\
\hline $6-9$ & $\mathrm{U}$ & 0 \\
\hline $10-9$ & A & 64 \\
\hline $10-5$ & $\mathrm{U}$ & 0 \\
\hline $9-5$ & $\mathrm{U}$ & 0 \\
\hline $9-4$ & $\mathrm{U}$ & 0 \\
\hline $5-4$ & $\mathrm{~A}$ & 64 \\
\hline $5-1$ & $\mathrm{U}$ & 0 \\
\hline $4-1$ & $\mathrm{U}$ & 0 \\
\hline $4-8$ & $\mathrm{X}$ & -1024 \\
\hline $1-8$ & $\mathrm{U}$ & 0 \\
\hline \multicolumn{2}{|c|}{ Total } & -764 \\
\hline
\end{tabular}

Gambar 4. Layout 2 dan Nilai Score 
Tabel 7. Nilai OMH Alternatif 3

\begin{tabular}{|c|c|c|c|c|c|c|c|c|c|}
\hline No & From & To & $\begin{array}{c}\text { Jarak } \\
\text { (m) }\end{array}$ & $\begin{array}{c}\text { Total } \\
\text { Jarak } \\
(\mathbf{m}) \\
\end{array}$ & $\begin{array}{c}\text { Jenis } \\
\text { Transport }\end{array}$ & $\begin{array}{c}\text { Biaya } \\
\text { Transport }\end{array}$ & OMH per meter & OMH & $\begin{array}{l}\text { Total } \\
\text { OMH }\end{array}$ \\
\hline 1 & $\begin{array}{c}\text { Bahan } \\
\text { baku }\end{array}$ & $\begin{array}{l}\text { Pemotongan } \\
\text { gergaji mesin }\end{array}$ & 44,21 & & $\begin{array}{l}\text { Tenaga } \\
\text { manusia }\end{array}$ & & & 3208,46 & \\
\hline 2 & $\begin{array}{l}\text { Pemotongan } \\
\text { gergaji mesin }\end{array}$ & Pemolaan & 2,02 & & $\begin{array}{l}\text { Tenaga } \\
\text { manusia }\end{array}$ & & & 146,60 & \\
\hline 3 & Pemolaan & $\begin{array}{l}\text { Pemotongan } \\
\text { mesin circle }\end{array}$ & 3,09 & & $\begin{array}{l}\text { Tenaga } \\
\text { manusia }\end{array}$ & & & 224,25 & \\
\hline 4 & $\begin{array}{l}\text { Pemotongan } \\
\text { mesin circle }\end{array}$ & $\begin{array}{l}\text { Pembubutan } \\
\text { bagian luar }\end{array}$ & 19,87 & & $\begin{array}{l}\text { Tenaga } \\
\text { manusia }\end{array}$ & 50000 & 72,57 & 1442,03 & \\
\hline 5 & $\begin{array}{l}\text { Pembubutan } \\
\text { bagian luar }\end{array}$ & $\begin{array}{l}\text { Pembubutan } \\
\text { bagian dalam }\end{array}$ & 2,05 & 171,76 & $\begin{array}{l}\text { Tenaga } \\
\text { manusia }\end{array}$ & & & 148,77 & 12465,5 \\
\hline 6 & $\begin{array}{l}\text { Pembubutan } \\
\text { bagian dalam }\end{array}$ & $\begin{array}{l}\text { Pengamplasan } \\
\text { mesin gerinda }\end{array}$ & 52,83 & & $\begin{array}{l}\text { Tenaga } \\
\text { manusia }\end{array}$ & & & 3834,04 & \\
\hline 7 & $\begin{array}{c}\text { Pengamplasan } \\
\text { mesin gerinda }\end{array}$ & Pengovenan & 37,83 & & $\begin{array}{c}\text { Tenaga } \\
\text { manusia }\end{array}$ & & & 2745,44 & \\
\hline 8 & Pengovenan & Pengecatan & 0,25 & & $\begin{array}{l}\text { Tenaga manusia } \\
\text { (Gerobak) }\end{array}$ & 50833,33 & 73,78 & 18,45 & \\
\hline 9 & Pengecatan & $\begin{array}{c}\text { Gudang } \\
\text { produk jadi }\end{array}$ & 9,61 & & $\begin{array}{c}\text { Tenaga } \\
\text { manusia } \\
\end{array}$ & 50000 & 72,57 & 697,43 & \\
\hline
\end{tabular}

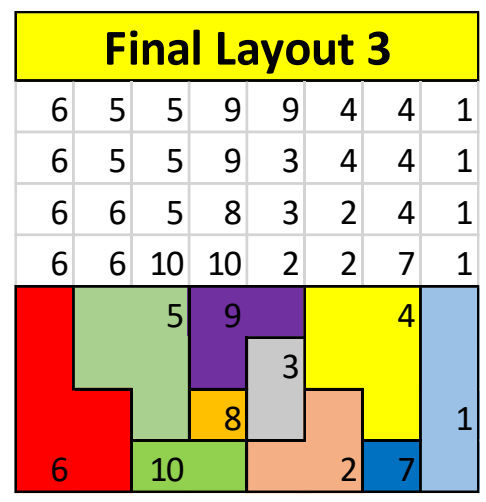

\begin{tabular}{|c|c|c|}
\hline $\begin{array}{c}\text { Adjacency } \\
\text { Departemen }\end{array}$ & Hubungan & Nilai Score \\
\hline $6-5$ & A & 64 \\
\hline $6-10$ & $\mathrm{U}$ & 0 \\
\hline $5-10$ & $\mathrm{U}$ & 0 \\
\hline $5-8$ & $\mathrm{O}$ & 1 \\
\hline $5-9$ & $\mathrm{U}$ & 0 \\
\hline $10-8$ & $\mathrm{U}$ & 0 \\
\hline $10-2$ & $\mathrm{U}$ & 0 \\
\hline $8-9$ & A & 64 \\
\hline $8-3$ & U & 0 \\
\hline $9-3$ & $\mathrm{U}$ & 0 \\
\hline $9-4$ & U & 0 \\
\hline $3-2$ & A & 64 \\
\hline $3-4$ & A & 64 \\
\hline $2-4$ & $\mathrm{X}$ & -1024 \\
\hline $2-7$ & $\mathrm{U}$ & 0 \\
\hline $4-7$ & $\mathrm{O}$ & 1 \\
\hline $4-1$ & U & 0 \\
\hline $7-1$ & $\mathrm{U}$ & 0 \\
\hline \multicolumn{2}{|c|}{ Total } & -766 \\
\hline
\end{tabular}

Gambar 5. Layout 3 dan Nilai Score 
Tabel 8. Nilai OMH Alternatif 4

\begin{tabular}{|c|c|c|c|c|c|c|c|c|c|}
\hline No & From & To & $\begin{array}{c}\text { Jarak } \\
\text { (m) }\end{array}$ & $\begin{array}{c}\text { Total } \\
\text { Jarak } \\
(\mathbf{m})\end{array}$ & $\begin{array}{c}\text { Jenis } \\
\text { Transport }\end{array}$ & $\begin{array}{c}\text { Biaya } \\
\text { Transport }\end{array}$ & OMH per meter & ОМН & $\begin{array}{l}\text { Total } \\
\text { OMH }\end{array}$ \\
\hline 1 & $\begin{array}{c}\text { Bahan } \\
\text { baku }\end{array}$ & $\begin{array}{l}\text { Pemotongan } \\
\text { gergaji mesin }\end{array}$ & 1,08 & & $\begin{array}{l}\text { Tenaga } \\
\text { manusia }\end{array}$ & & & 78,38 & \\
\hline 2 & $\begin{array}{l}\text { Pemotongan } \\
\text { gergaji mesin }\end{array}$ & Pemolaan & 10,67 & & $\begin{array}{l}\text { Tenaga } \\
\text { manusia }\end{array}$ & & & 774,36 & \\
\hline 3 & Pemolaan & $\begin{array}{l}\text { Pemotongan } \\
\text { mesin circle }\end{array}$ & 9,14 & & $\begin{array}{l}\text { Tenaga } \\
\text { manusia }\end{array}$ & & & 663,32 & \\
\hline 4 & $\begin{array}{l}\text { Pemotongan } \\
\text { mesin circle }\end{array}$ & $\begin{array}{c}\text { Pembubutan } \\
\text { bagian luar }\end{array}$ & 30,28 & & $\begin{array}{l}\text { Tenaga } \\
\text { manusia }\end{array}$ & 50000 & 72,57 & 2197,52 & \\
\hline 5 & $\begin{array}{c}\text { Pembubutan } \\
\text { bagian luar }\end{array}$ & $\begin{array}{l}\text { Pembubutan } \\
\text { bagian dalam }\end{array}$ & 19,77 & 185,14 & $\begin{array}{l}\text { Tenaga } \\
\text { manusia }\end{array}$ & & & 1434,77 & 13464,53 \\
\hline 6 & $\begin{array}{l}\text { Pembubutan } \\
\text { bagian dalam }\end{array}$ & $\begin{array}{l}\text { Pengamplasan } \\
\text { mesin gerinda }\end{array}$ & 8,09 & & $\begin{array}{l}\text { Tenaga } \\
\text { manusia }\end{array}$ & & & 587,12 & \\
\hline 7 & $\begin{array}{l}\text { Pengamplasan } \\
\text { mesin gerinda }\end{array}$ & Pengovenan & 39,17 & & $\begin{array}{l}\text { Tenaga } \\
\text { manusia }\end{array}$ & & & 2842,69 & \\
\hline 8 & Pengovenan & Pengecatan & 23,43 & & $\begin{array}{c}\text { Tenaga manusia } \\
\text { (Gerobak) }\end{array}$ & 50833,33 & 73,78 & 1728,73 & \\
\hline 9 & Pengecatan & $\begin{array}{c}\text { Gudang } \\
\text { produk jadi }\end{array}$ & 43,51 & & $\begin{array}{l}\text { Tenaga } \\
\text { manusia }\end{array}$ & 50000 & 72,57 & 3157,66 & \\
\hline
\end{tabular}

\section{Final Layout 4}

\begin{tabular}{|c|c|c|c|c|c|c|c|}
\hline 4 & 6 & 6 & 2 & 2 & 5 & 5 & 10 \\
\hline 4 & 3 & 6 & 2 & 1 & 5 & 5 & 10 \\
\hline 4 & 3 & 6 & 7 & 1 & 5 & 9 & 8 \\
\hline 4 & 4 & 6 & 6 & 1 & 1 & 9 & 9 \\
\hline & & 6 & & & 5 & & 10 \\
\hline 4 & & & 7 & 1 & & 9 & 8 \\
\hline
\end{tabular}

\begin{tabular}{|c|c|c|}
\hline $\begin{array}{l}\text { Adjacency } \\
\text { Departemen }\end{array}$ & Hubungan & Nilai Score \\
\hline $4-3$ & $\mathrm{~A}$ & 64 \\
\hline $4-6$ & $\mathrm{O}$ & 0 \\
\hline $3-6$ & I & 4 \\
\hline $5-8$ & $\mathrm{O}$ & 1 \\
\hline $6-7$ & A & 64 \\
\hline $6-2$ & $\mathrm{U}$ & 0 \\
\hline $6-1$ & $\mathrm{U}$ & 0 \\
\hline $7-2$ & $\mathrm{U}$ & 0 \\
\hline $7-1$ & $\mathrm{U}$ & 0 \\
\hline $2-1$ & A & 64 \\
\hline $2-5$ & $\mathrm{U}$ & 0 \\
\hline $1-5$ & $\mathrm{U}$ & 0 \\
\hline $1-9$ & $\mathrm{U}$ & 0 \\
\hline $5-9$ & $\mathrm{U}$ & 0 \\
\hline $5-10$ & $\mathrm{U}$ & 0 \\
\hline $9-8$ & A & 64 \\
\hline $8-10$ & $\mathrm{U}$ & 0 \\
\hline \multicolumn{2}{|c|}{ Total } & 261 \\
\hline
\end{tabular}

Gambar 6. Layout 4 dan Nilai Score 
Tabel 9. Nilai OMH Alternatif 5

\begin{tabular}{|c|c|c|c|c|c|c|c|c|c|}
\hline No & From & To & $\begin{array}{c}\text { Jarak } \\
\text { (m) }\end{array}$ & $\begin{array}{c}\text { Total } \\
\text { Jarak } \\
(\mathbf{m}) \\
\end{array}$ & $\begin{array}{c}\text { Jenis } \\
\text { Transport }\end{array}$ & $\begin{array}{c}\text { Biaya } \\
\text { Transport }\end{array}$ & OMH per meter & ОМН & $\begin{array}{l}\text { Total } \\
\text { OMH }\end{array}$ \\
\hline 1 & $\begin{array}{c}\text { Bahan } \\
\text { baku }\end{array}$ & $\begin{array}{l}\text { Pemotongan } \\
\text { gergaji mesin }\end{array}$ & 2,92 & & $\begin{array}{l}\text { Tenaga } \\
\text { manusia }\end{array}$ & & & 211,91 & \\
\hline 2 & $\begin{array}{l}\text { Pemotongan } \\
\text { gergaji mesin }\end{array}$ & Pemolaan & 2 & & $\begin{array}{l}\text { Tenaga } \\
\text { manusia }\end{array}$ & & & 145,15 & \\
\hline 3 & Pemolaan & $\begin{array}{l}\text { Pemotongan } \\
\text { mesin circle }\end{array}$ & 0,64 & & $\begin{array}{l}\text { Tenaga } \\
\text { manusia }\end{array}$ & & & 46,45 & \\
\hline 4 & $\begin{array}{l}\text { Pemotongan } \\
\text { mesin circle }\end{array}$ & $\begin{array}{l}\text { Pembubutan } \\
\text { bagian luar }\end{array}$ & 16,92 & & $\begin{array}{l}\text { Tenaga } \\
\text { manusia }\end{array}$ & 50000 & 72,57 & 1227,94 & \\
\hline 5 & $\begin{array}{l}\text { Pembubutan } \\
\text { bagian luar }\end{array}$ & $\begin{array}{l}\text { Pembubutan } \\
\text { bagian dalam }\end{array}$ & 2 & 131,18 & $\begin{array}{l}\text { Tenaga } \\
\text { manusia }\end{array}$ & & & 145,15 & 9614,56 \\
\hline 6 & $\begin{array}{l}\text { Pembubutan } \\
\text { bagian dalam }\end{array}$ & $\begin{array}{l}\text { Pengamplasan } \\
\text { mesin gerinda }\end{array}$ & 3,07 & & $\begin{array}{l}\text { Tenaga } \\
\text { manusia }\end{array}$ & & & 222,80 & \\
\hline 7 & $\begin{array}{l}\text { Pengamplasan } \\
\text { mesin gerinda }\end{array}$ & Pengovenan & 9,5 & & $\begin{array}{l}\text { Tenaga } \\
\text { manusia }\end{array}$ & & & 689,44 & \\
\hline 8 & Pengovenan & Pengecatan & 78,06 & & $\begin{array}{c}\text { Tenaga manusia } \\
\text { (Gerobak) }\end{array}$ & 50833,33 & 73,78 & 5759,48 & \\
\hline 9 & Pengecatan & $\begin{array}{c}\text { Gudang } \\
\text { produk jadi }\end{array}$ & 16,07 & & $\begin{array}{l}\text { Tenaga } \\
\text { manusia }\end{array}$ & 50000 & 72,57 & 1166,25 & \\
\hline
\end{tabular}

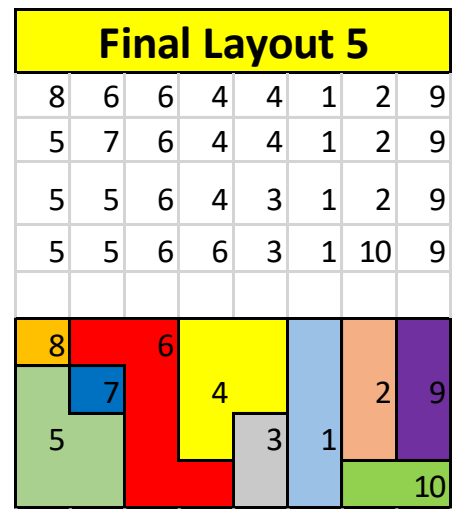

\begin{tabular}{|c|c|c|}
\hline $\begin{array}{l}\text { Adjacency } \\
\text { Departemen }\end{array}$ & Hubungan & Nilai Score \\
\hline $8-5$ & $\mathrm{O}$ & 1 \\
\hline $8-6$ & $\mathrm{O}$ & 1 \\
\hline $5-7$ & $\mathrm{O}$ & 1 \\
\hline $5-6$ & A & 64 \\
\hline $6-9$ & $\mathrm{U}$ & 0 \\
\hline $7-6$ & A & 64 \\
\hline $6-4$ & $\mathrm{O}$ & 1 \\
\hline $6-3$ & I & 4 \\
\hline $4-3$ & A & 64 \\
\hline $4-1$ & $\mathrm{U}$ & 0 \\
\hline $3-1$ & $\mathrm{U}$ & 0 \\
\hline $1-2$ & A & 64 \\
\hline $1-10$ & $\mathrm{U}$ & 0 \\
\hline $2-10$ & $\mathrm{U}$ & 0 \\
\hline $2-9$ & $\mathrm{U}$ & 0 \\
\hline $10-9$ & A & 64 \\
\hline
\end{tabular}

Gambar 7. Layout 5 dan Nilai Score 
Tabel 10. Nilai OMH Alternatif 6

\begin{tabular}{|c|c|c|c|c|c|c|c|c|c|}
\hline No & From & To & $\begin{array}{c}\text { Jarak } \\
\text { (m) }\end{array}$ & $\begin{array}{c}\text { Total } \\
\text { Jarak } \\
\text { (m) } \\
\end{array}$ & $\begin{array}{c}\text { Jenis } \\
\text { Transport }\end{array}$ & $\begin{array}{c}\text { Biaya } \\
\text { Transport }\end{array}$ & OMH per meter & OMH & $\begin{array}{l}\text { Total } \\
\text { OMH }\end{array}$ \\
\hline 1 & $\begin{array}{c}\text { Bahan } \\
\text { baku }\end{array}$ & $\begin{array}{l}\text { Pemotongan } \\
\text { gergaji mesin }\end{array}$ & 5,43 & & $\begin{array}{l}\text { Tenaga } \\
\text { manusia }\end{array}$ & & & 394,07 & \\
\hline 2 & $\begin{array}{l}\text { Pemotongan } \\
\text { gergaji mesin }\end{array}$ & Pemolaan & 12,86 & & $\begin{array}{l}\text { Tenaga } \\
\text { manusia }\end{array}$ & & & 933,29 & \\
\hline 3 & Pemolaan & $\begin{array}{l}\text { Pemotongan } \\
\text { mesin circle }\end{array}$ & 2,06 & & $\begin{array}{l}\text { Tenaga } \\
\text { manusia }\end{array}$ & & & 149,50 & \\
\hline 4 & $\begin{array}{l}\text { Pemotongan } \\
\text { mesin circle }\end{array}$ & $\begin{array}{l}\text { Pembubutan } \\
\text { bagian luar }\end{array}$ & 8,25 & & $\begin{array}{l}\text { Tenaga } \\
\text { manusia }\end{array}$ & 50000 & 72,57 & 598,73 & \\
\hline 5 & $\begin{array}{l}\text { Pembubutan } \\
\text { bagian luar }\end{array}$ & $\begin{array}{l}\text { Pembubutan } \\
\text { bagian dalam }\end{array}$ & 10,66 & 104,43 & $\begin{array}{l}\text { Tenaga } \\
\text { manusia }\end{array}$ & & & 773,63 & 7632,82 \\
\hline 6 & $\begin{array}{l}\text { Pembubutan } \\
\text { bagian dalam }\end{array}$ & $\begin{array}{l}\text { Pengamplasan } \\
\text { mesin gerinda }\end{array}$ & 1 & & $\begin{array}{l}\text { Tenaga } \\
\text { manusia }\end{array}$ & & & 72,57 & \\
\hline 7 & $\begin{array}{c}\text { Pengamplasan } \\
\text { mesin gerinda }\end{array}$ & Pengovenan & 3,45 & & $\begin{array}{r}\text { Tenaga } \\
\text { manusia }\end{array}$ & & & 250,38 & \\
\hline 8 & Pengovenan & Pengecatan & 44,65 & & $\begin{array}{c}\text { Tenaga manusia } \\
\text { (Gerobak) }\end{array}$ & 50833,33 & 73,78 & 3294,40 & \\
\hline 9 & Pengecatan & $\begin{array}{c}\text { Gudang } \\
\text { produk jadi }\end{array}$ & 16,07 & & $\begin{array}{c}\text { Tenaga } \\
\text { manusia }\end{array}$ & 50000 & 72,57 & 1166,25 & \\
\hline
\end{tabular}

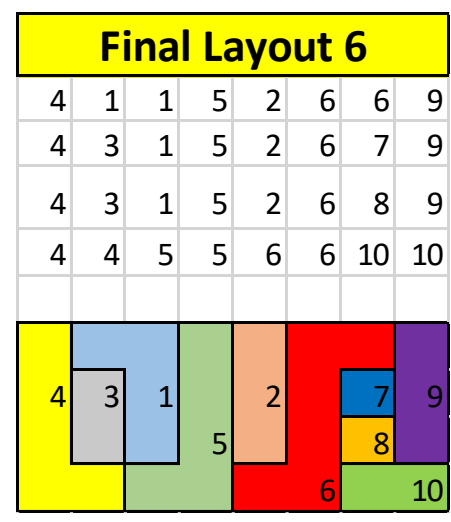

\begin{tabular}{|c|c|c|}
\hline $\begin{array}{c}\text { Adjacency } \\
\text { Departemen }\end{array}$ & Hubungan & Nilai Score \\
\hline $4-3$ & A & 64 \\
\hline $4-1$ & U & 0 \\
\hline $4-5$ & A & 64 \\
\hline $3-1$ & $\mathrm{U}$ & 0 \\
\hline $1-5$ & $\mathrm{U}$ & 0 \\
\hline $5-2$ & $\mathrm{U}$ & 0 \\
\hline $5-6$ & A & 64 \\
\hline $2-6$ & $\mathrm{U}$ & 0 \\
\hline $4-3$ & A & 64 \\
\hline $6-7$ & A & 64 \\
\hline $6-8$ & $\mathrm{O}$ & 1 \\
\hline $6-10$ & U & 0 \\
\hline $7-8$ & A & 64 \\
\hline $7-9$ & U & 0 \\
\hline $8-10$ & $\mathrm{U}$ & 0 \\
\hline $8-9$ & A & 64 \\
\hline $10-9$ & A & 64 \\
\hline \multicolumn{2}{|c|}{ Total } & 513 \\
\hline
\end{tabular}

Gambar 8. Layout 6 dan Nilai Score

Setelah dilakukan perancangan existing layout dan alternatif layout sebanyak 6 kali dengan metode Automated Layout Design Program (ALDEP) didapatkan hasil layout dengan jarak perpindahan material dan ongkos material handling (OMH) yang berbeda-beda. Dari hasil pembahasan di atas, pemilihan layout alternatif yang dipilih oleh penulis berdasarkan ketentuan layout terpilih dari metode Automated Layout Design Program (ALDEP) adalah layout alternatif dengan nilai score terbesar. Jadi layout alternatif yang dipilih sesuai dengan ketentuan metode Automated Layout Design Program (ALDEP) adalah layout alternatif 6. 


\section{Kesimpulan}

Metode Algoritma Layout Design Program (ALDEP) merupakan salah satu metode konstruksi dimana metode ini akan menghasilkan tata letak baru tanpa memandang tata letak yang ada atau existing layout. Pemilihan metode ALDEP pada penelitian ini karena dapat menghasilkan tata letak yang memperhatikan keterkaitan antar departemen kerja, alur produksi, dan jarak perpindahan. Pada perancangan dengan algoritma ALDEP terbagi atas 2 prosedur, yaitu prosedur pemilihan dan penempatan. Berdasarkan hasil penelitian maka didapatkan 6 alternatif layout. Alternatif layout terbaik menurut metode ALDEP adalah alternatif layout 6 karena alternatif layout 6 memiliki nilai score terbesar yaitu sebesar 513 dengan total jarak perpindahan sebesar 104,43 meter dan nilai OMH sebesarRp 7.632,82.-.

\section{Daftar Pustaka}

Aleisa, E. E., \& Lin, L. (2005). For effective facilities planning: layout optimization then simulation, or vice versa? Proceedings of the Winter Simulation Conference. Orlando, FL, USA: IEEE.

Andryzio, Fifi Herni Mustofa, \& Lisye Fitria. (2014). Usulan Perancangan Tata Letak Fasilitas Dengan Menggunakan Metode Automated Layout Design Program (ALDEP) di CV. Kawani Tekno Nusantara. Reka Integra, 2(4), 365-376.

James M. Apple. (1990). Tataletak Pabrik dan Pemindahan Bahan (3rd ed.). Bandung: ITB Bandung.

Maheswari, H., \& Dany Firdauzy, A. (2015). Evaluasi Tata Letak Fasilitas Produksi Untuk Meningkatkan Efisiensi Kerja Pada PT. Nusa Multilaksana. Jurnal Ilmiah Manajemen Dan Bisnis, 1(3).

Prasetya, Y. Y., Runtuk, J. K., \& Hartanti, L. P. (2015). Analisis Tata Letak Fasilitas dalam Meminimasi Material Handling (Studi Kasus: Perusahaan Roti Matahari). Jurnal GEMA AKTUALITA, 4(1), 1-10. Retrieved from http://ditjenkpi.kemendag.go.id

Purnomo, H. (2004). Perencanaan dan
Perancangan Fasilitas (1st ed.). Yogyakarta: Graha Ilmu.

Rosyidi, M. R. (2018). Analisa Tata Letak Fasilitas Produksi dengan Metode ARC, ARD, dan AAD di PT. XYZ. Jurnal Teknik WAKTU, 16(1), 82-95.

Rubianto, C. N., \& Bendatu, L. Y. (2014). Penentuan Lokasi dan Perancangan Tata Letak Fasilitas Tempat Packaging PT.ABC. Jurnal Titra, 2(2), 65-70.

Tarigan, U., Tarigan, U. P. P., \& Dalimunthe, Z. A. (2017). Aplikasi Algoritma Block Plan dan ALDEP dalam Perancangan Ulang Tata Letak Fasilitas Produksi Pabrik Pengolahan Karet. Seminar Nasional Teknik Industri [SNTI2017, 313-322. Lhokseumawe, Aceh.

Tika Pamularsih, Fifi Herni Mustofa, \& Susy Susanty. (2015). Usulan Rancangan Tata Letak Fasilitas Dengan Menggunakan Metode Automated Layout Design Program (ALDEP) di EDEM Ceramic. Reka Integra, 3(2), 339-350.

Tompkins, J. A., White, J. A., Bozer, Y. A., \& Tanchoco, J. M. A. (2010). Facilities Planning (4th ed.). USA: John Wiley \& Sons.

Ulfa, A. R., Susanty, S., \& Mustofa, F. H. (2015). Usulan Rancangan Tata Letak Fasilitas Produksi Produk Selang dengan Menggunakan Automated Layout Design Program (ALDEP) di PT. Inkaba Bandung. Reka Integra, 3(2), 271-280.

Wahyudi, E. S. (2010). Perancangan Ulang Tata Letak Fasilitas Produksi di CV. Dimas Rotan Gatak Sukoharjo. Jurusan Teknik Industri, Fakultas Teknik, Universitas Sebelas Maret.

Wignjosoebroto, S. (2009). Tata Letak Pabrik dan Pemindahan Bahan (3rd ed.). Surabaya: Guna Widya.

Yuliant, R., Saleh, A., \& Bakar, A. (2014). Usulan Perancangan Tata Letak Fasilitas Perusahaan Garmen CV. X dengan Menggunakan Metode Konvensional. Reka Integra, 2(3), 7283. 